Enferm Bras 2020;19(4Supl):S50-S55

https://doi.org/10.33233/eb.v19i4.4385

\title{
REVIEW \\ Home containment and COVID-19: a perspective about the mental health of the geriatric population
}

Nicolle dos Santos Moraes Nunes ${ }^{1}$, Jacqueline Stephanie Fernandes do Nascimento ${ }^{1}$, Maria Eduarda Abreu Rangel ${ }^{1}$, Esther Victória Lima de Mello ${ }^{1}$, Janie Kelly Fernandes do Nascimento ${ }^{1}$, Marco Antônio Alves Azizi², Adalgiza Mafra Moreno ${ }^{3}$, Marco Antônio Orsini Neves ${ }^{4}$

${ }^{1}$ Graduate student at the Iguaçu University Medical School, Universidade Iguaçu UNIG-RJ, Nova Iguaçu/RJ, Brazil, ${ }^{2} M D$, Full Professor at the Iguaçu University, Iguaçu University UNIG-RJ, Nova Iguaçu/RJ, Brazil, ${ }^{3}$ Full Professor at the Iguaçu University, Iguaçu University UNIG-RJ, Nova Iguaçu/RJ, Brazil, ${ }^{4} M D$, Post Doctor at the Federal University of Rio de Janeiro, Full Professor at the Iguaçu University, Iguaçu University UNIG-RJ, Nova Iguaçu/RJ, Brazil

Received on July 15th, 2020; accepted on August 15th, 2020.

Corresponding author: Janie Kelly Fernandes do Nascimento, Av. Dr. Mário Guimarães 863/1603 Centro 26255230 Nova Iguaçu RJ

Nicolle dos Santos Moraes Nunes: nicolle.nunes_@hotmail.com.br Jacqueline Stephanie Fernandes do Nascimento: jac.fn@hotmail.com

Maria Eduarda Abreu Rangel: dudaabreur16@hotmail.com

Esther Victória Lima de Mello: melloesthervictoria@gmail.com

Janie Kelly Fernandes do Nascimento: janiekelly@hotmail.com

Marco Antônio Alves Azizi: marcoazizimed@gmail.com

Adalgiza Mafra Moreno: adalgizamoreno@hotmail.com

Marco Antônio Orsini Neves: orsinimarco@hotmail.com

\begin{abstract}
Introduction: The COVID-19 pandemic is a major Public Health problem today. Social isolation is the main measure established so far to delay the spread of this pathology. However, the loneliness resulting from confinement can be particularly problematic in senescence. This article aimed to produce and update reflections about the impact of social isolation on the mental health of the elderly during the COVID-19 pandemic. Methodology: A search was carried out in the main data sources: Lilacs, Bireme and Pubmed, in Portuguese and English. Articles that address inclusion requirements were selected and exclude those that do not. It was also decided to perform a reverse search, in order to expand and diversify the results. Results: By crossing the keywords in the database, a total of 475 publications were found. Joining selected articles in the database and in the reverse search, the sample was composed of 21 articles in all. Conclusion: Social isolation negatively affects the mental health of the elderly. Thus, health professionals must be prepared to face an epidemic of emotional disorders arising from the confinement of this population.
\end{abstract}

Keywords: elderly, mental health, pandemic, COVID-19, social isolation.

\section{Resumo}

Confinamento domiciliar e covid-19: uma perspectiva acerca da saúde mental da população geriátrica

Introdução: A pandemia de COVID-19 é um grande problema de saúde pública atualmente. O isolamento social é a principal medida estabelecida até o momento para retardar a disseminação dessa patologia. No entanto, a solidão resultante do confinamento pode ser particularmente problemática na senescência. Este artigo tem como objetivo produzir e atualizar reflexões acerca do impacto do isolamento social sobre a saúde mental de idosos durante a pandemia de COVID19. Metodologia: Foi realizada uma busca nas principais fontes de dados: Lilacs, Bireme e Pubmed, em português e inglês. Foram selecionados artigos que abordassem os critérios de inclusão, e excluídos os que não abordassem. Optou-se também por realizar uma busca reversa, no intuito de ampliar e diversificar os resultados. Resultados: Através do cruzamento dos 
descritores na base de dados foi encontrado um total de 475 publicações. Unindo artigos selecionados na base de dados e na busca reversa, a amostra foi composta por 21 artigos ao todo. Conclusão: $O$ isolamento social gera impactos negativos acerca da saúde mental da população geriátrica devido à exacerbação de sentimentos negativos provocados por ele. Assim, os profissionais de saúde devem estar preparados para enfrentar uma epidemia de distúrbios emocionais decorrentes do confinamento dessa população.

Palavras-chave: idosos, saúde mental, pandemia, COVID-19, isolamento social.

\section{Resumen}

Contención en la casa y covid-19: una perspectiva sobre la salud de la poblacion geriátrica Introducción: La pandemia de COVID-19 es un importante problema de salud pública en la actualidad. aislamiento social es la principal medida utilizada hasta ahora para retrasar la propagación de esta patología. Entonces la soledad resultante del confinamiento puede ser particularmente problemática en la vejez. Este artículo tiene como objetivo producir y actualizar reflexiones sobre el impacto del aislamiento social en la salud mental de las personas durante la pandemia de COVID-19. Metodología: Se realizaron búsquedas de las principales fuentes de datos: Lilacs, Bireme y Pubmed, en portugués y inglés. Se seleccionaron los artículos que abordaban los criterios de inclusión y se excluyeron los que no. Fue decidido realizar una búsqueda inversa para expandir y diversificar los resultados. Resultados: Al cruzar los descriptores en la base de datos, se encontraron un total de 475 publicaciones. Uniéndose a los artículos seleccionados en la base de datos y en la búsqueda inversa, la muestra estaba compuesta por 21 artículos en total. Conclusión: El aislamiento social afecta negativamente la salud mental de los ancianos al exacerbar los sentimientos negativos. Por lo tanto, los profesionales de la salud deben estar preparados para enfrentar una epidemia de trastornos emocionales resultantes del confinamiento de esta población.

Palabras-clave: ancianos, salud mental, pandemia, COVID-19, aislamiento social

Introduction

The COVID-19 pandemic is the biggest Public Health problem of the century. The number of new cases increases gradually in several countries. This fact becomes important since the feeling of danger and threat of illness generate damage to mental health [1]. Social isolation is the main measure established so far, in Brazil, to delay the spread of the disease. Although necessary, isolation is related to the exacerbation of pre-existing psychiatric disorders and the development of new conditions [2]. Disorders such as anxiety, depression and insomnia have been the most related to the pandemic [2].

Classified by the World Health Organization (WHO) as the group of greatest vulnerability to SARS-Cov-2 infection, the elderly, in addition to previous comorbidities, naturally have the characteristic of immunosenescence [3]. Immunosenescence is a physiological process of metabolic reduction that directly influences the immune response of these individuals, increasing the chances of unfavorable prognosis for COVID-19 [4]. By ensuring the guidelines of the Ministry of Health [5], regarding the prevention of the elderly to such infection, the aggravating factor consists in the exacerbation of feelings and emotions promoted by total isolation when changing the routine of these individuals. Studies show that loneliness is an independent risk factor for depression in old age [6].

Aging is characterized as a biopsychosocial process of changes that occur over the life of an individual [7]. It is a multidimensional process centered on the correlation between biological, psychological and social factors. It is estimated that by 2050 there will be more than 2 billion elderly people living in developing countries [8]. The growth of the elderly population reinforces the need for a more detailed look at their needs and vulnerabilities. Thus, it is essential to assess the negative impacts of the pandemic on the mental health of the geriatric population, and the alternatives that demonstrate better results to mitigate them.

The outburst of mental health problems during a pandemic is common, as reported in previous episodes [9-11]. Excessive exposure to drastic news, abrupt interruption of routine, and social distance are factors that can contribute to unfavorable outcomes in mental health of elderly [12]. The objective of the present study is, through a brief literature review, to characterize the negative impacts of home confinement on the mental health of the geriatric population during the COVID-19 pandemic. 
The purpose of this article is, based on current literature, to produce and update reflections about the current pandemic context. For this, a literature review had been carried out through articles that address the theme of home confinement necessary due to the COVID-19 pandemic, and its impacts on the mental health of the elderly.

The databases used were PubMed, Lilacs, Bireme, which are considered important scientific bases of international scope. In this study, it was decided not to limit the year of publication of the articles, expanding the results for study. In addition, it was also opted to perform a reverse search, an article search technique based on the investigation of the references of the articles selected for the sample, in order to expand and diversify the results.

The inclusion criteria for the sample were: articles that addressed psychological damage related to the COVID-19 pandemic, the theme of loneliness, depressive symptoms and insomnia in the geriatric population. The exclusion criteria were articles that did not address the afore mentioned themes. The descriptors indexed in the DeCS "social isolation", "COVID-19", "mental health", "insomnia", "health of the elderly" and their respective descriptors in Portuguese were used.

The process of eligibility of articles for the sample of this review followed three steps: reading the title to suit the theme of the impacts of the pandemic on the mental health of the elderly; reading the summary to investigate your ability to answer the guiding question; and reading the full articles in order to extract the data for later summarization of the outcomes.

Results

By crossing the descriptors in the database, a total of 475 publications were found. Joining selected articles in the database and in the reverse search, the sample was composed of 21 articles in all.

The mental health of the geriatric population is often neglected [12]. It is believed that this is related to a belief that the decline in mental health in this group is a normal part of the aging process, in addition to the lack of awareness about the symptoms of mental illness in the elderly [13]. Studies show that living alone, or in a nursing home, and the presence of other comorbidities are also related to prevalence of depression in this group [14].

A cross-sectional study conducted in China revealed that more than half of the participants demonstrated feelings of psychological distress secondary to the outbreak of COVID19 [15]. Isolation during the SARS-CoV-2 pandemic tends to affect mainly the elderly who have social contact exclusively outside the home, those who live in long-term homes or without a family nucleus, those who have no spouse, as well as those who depend on voluntary services and social assistance [16,17].

Isolation among the elderly can be associated with secondary morbidity and mortality, neurocognitive complications, and mental health problems [18,19]. In a study conducted in France, markers of vulnerability were identified among psychiatric patients during the COVID-19 pandemic, among which stood out: advanced age, difficulty in fulfilling confinement and hygiene measures due to cognitive and behavioral disorders [20]. Therefore, it is valid to emphasize the geriatric vulnerability and the high risk of exacerbation of psychiatric, cognitive disorders and loss of autonomy within of the pandemic outlook.

Studies carried out in Hong Kong, during the epidemic of Severe Acute Respiratory Syndrome (SARS), demonstrated an increase in suicidal events, especially in women over 65 years of age $[21,22]$. Likewise, the confinement resulting from the COVID-19 pandemic, and its financial stressors, are related to the exacerbation of psychiatric disorders that increase the risk of suicide, such as: depression, anxiety and post-traumatic stress. In addition to these, domestic violence, mistreatment and alcohol abuse are also precipitating suicide that can be adversely increased by isolation [2].

Insomnia is the most common sleep disorder among the elderly [23]. It is believed that its highest prevalence in this age group is related to the combination of physical and mental health comorbidities associated with aging [24]. The anxiety caused by confinement tends to aggravate 
this situation, leading to very negative impacts on the quality of life of the elderly, such as: increased risk of falls, psychological and physical illnesses, in addition to economic and social costs [24].

A study showed that the COVID-19 pandemic reduced the number of elderly people doing physical activity [26]. When interviewed, these elderly people demonstrated to perceive the negative impacts of this reduction on their well-being [25]. While isolation protects them from infection, it also makes it difficult to perform daily activities, such as physical exercise, generating a greater risk of functional decline $[25,26]$.

In Australia, after the implementation of the social distancing protocols to reduce the spread of COVID-19, the government instituted advances in telehealth due to the concern with patients with chronic diseases who need regular consultations with their general practitioners, promoting a reduction in the rate of grievances [27]. Another study, carried out in a nursing home in Taiwan, showed a significant reduction in the feeling of loneliness among residents after videoconferences on virtual platforms [28]. Within this context, the use of Digital Information and Communication Technologies (ICT) appears as a possible tool to mitigate negative impacts on both mental and physical health [29]. Even so, the elderly have limited access to technological tools when compared to younger patients, which can be a factor that hinders accessibility to them.

Although little is known about the extent of the negative impacts of the pandemic among the geriatric population, it is a fact that mental health professionals must be prepared to face an epidemic of emotional disorders caused by the confinement of the population $[16,20]$. Within this context, it is essential that patients are well informed about the various negative feelings that will arise during the pandemic. However, if these symptoms become too frequent and intense, they should be advised to seek specialized professionals in mental health. Currently, it is suggested to recommend quality of sleep and regular daily routine, physical exercise, social interaction through virtual social networks, reduction of exposure time to drastic false information disseminated on social networks, in addition to encouraging the mobilization of the elderly patient's family so that they have the necessary support and dignity $[20,30]$.

\section{Conclusion}

The COVID-19 pandemic, social distance and other maneuvers for its control generate significant negative impacts on the mental health of the elderly. Although the mental health of this group is often neglected, the gradual growth in the population's life expectancy makes clear the importance and need for health policies aimed at the elderly. Psychiatric disorders such as depression and anxiety were the most described in the current literature, especially when associated with isolation. In addition, sleep disorders and increased suicide predictors also appear to have been adversely increased. The use of digital information and communication technologies seems promising in terms of reducing the feeling of loneliness during confinement, requiring further research related to measures that increase the accessibility and adherence of the geriatric population to them. Stimulating physical activity, reducing exposure to drastic news, cleaning sleep and mobilizing family members and caregivers also suggest benefits. There are still no concrete epidemiological data to corroborate the current negative psychological impacts of COVID-19, however, given the reports of previous outbreaks, mental health professionals must be prepared to face an epidemic of emotional disorders arising from the confinement of the population.

1. Liu S, Liu Y, Liu Y. Somatic symptoms and concern regarding COVID-19 among Chinese college and primary school students: A cross-sectional survey. Psychiatry Res 2020;28. https://doi.org/10.1016/j.psychres.2020.113070

2. Berk M, Vieta E, Dean OM. Suicide risk and prevention during the COVID-19 pandemic. The Lancet Psychiatry 2020;7(6):468-71. https://doi.org/10.1016/S22150366(20)30171-1

3. Brasil. Ministério da Sáude. Especial: doença pelo coronavírus 2019; 2020. https://www.saude.gov.br/images/pdf/2020/April/06/2020-04-06-BE7-Boletim-Especialdo-COE-Atualizacao-da-Avaliacao-de-Risco.pdf

4. Veras FPTV. Teorias biológicas do envelhecimento: do genético ao estocástico. Rev Bras Med Esporte 2002;8(4):129-138. https://doi.org/10.1590/S151786922002000400001 
5. Brasil. Ministério da Sáude. Portaria no 356, de 11 de março de 2020. 2020;49(1);185. http://www.in.gov.br/en/web/dou/-/portaria-n-356-de-11-de-marco-de-2020-247538346

6. Alpass FM, Neville S. Loneliness, health and depression in older males. Aging \& Mental Health 2003;7(3):212-6. https://pubmed.ncbi.nlm.nih.gov/12775403/?dopt=Abstract

7. Fonseca AM. Subsídios para uma leitura desenvolvimental do processo de envelhecimento. Psicol Reflex Crit 2007;20(2):277-289. https://doi.org/10.1590/S010279722007000200014

8. World Health Organization. Active Ageing: A policy framework. 2002. https://apps.who.int/iris/bitstream/handle/10665/67215/WHO NMH NPH 02.8.pdf

9. Lee AM, Wong JG, Mcalonan GM, Cheung V, Cheung C, Sham PC et al. Stress and psychological distress among SARS survivors 1 year after the outbreak. Can J Psychiatry 2007; 52: 233-40. https://doi.org/10.1177/070674370705200405

10. Brooks SK, Webster RK, Smith LE, Woodland L, Wessely S, Greenberg N et al. The psychological impact of quarantine and how to reduce it: rapid review of the evidence. The Lancet 2020;395:912-920. https://doi.org/10.1016/S0140-6736(20)30460-8

11. Bajardi P, Poletto C, Ramasco JJ, Tizzoni M, Colizza V, Vespignani A. Human mobility networks, travel restrictions, and the global spread of $2009 \mathrm{H} 1 \mathrm{~N} 1 \mathrm{Pandemic}$. Plos One 2011;6(1). https://doi.org/10.1371/journal.pone.0016591

12. Exposição demasiada a notícias drásticas, interrupção abrupta da rotina e dist social. WHO Saúde mental de idosos - Organização Mundial da Saúde. 2017. https://www.who.int/news-room/fact-sheets/detail/mental-health-of-older-adults

13. Sibai AM, Semaan A, Tabbara J, Risk A. Ageing and health in the Arab region: Challenges, opportunities and the way forward. Population Horizons 2017;14(2):73-84. https://doi.org/10.1515/pophzn-2017-0007

14. Mohamed E, Abdelhamed M. Depression among elderly attending geriatric clubs in Assiut City, Egypt. The Journal of American Science 2011. https://www.semanticscholar.org/paper/Depression-among-elderly-attending-geriatricclubs-MohamedAbdelhamed/d23d58519aabce78f6aac2d9e6268892867bb06c

15. Wang C, Pan R, Wan X, Tan Y, Xu L, Ho CS et al. Immediate psychological responses and associated factors during the initial stage of the 2019 Coronavirus Disease (COVID-19) Epidemic among the General Population in China. Int J Environ Res Public Health 2020;17(5). https://www.mdpi.com/1660-4601/17/5/1729

16. Hayek SM, Cheaito MA, Nofal M, Abdelrahman D, Adra A, Shamli AS et al. Geriatric mental health and COVID-19: An eye-opener to the situation of the Arab countries in the Middle East and North Africa Region. Am J Geriatr Psychiatry 2020. https://doi.org/10.1016/j.jagp.2020.05.009

17. Armitage R, Nellums LB. COVID-19 and the consequences of isolating the elderly. Lancet Public Health 2020;5(5):e256. https://doi.org/10.1016/s2468-2667(20)30061-x

18. Gerst-Emerson K, Jayawardhana J. Loneliness as a public health issue: the impact of Ioneliness on health care utilization among older adults. Am J Public Health 2015;105(5):1013-9. https://doi.org/10.2105/ajph.2014.302427

19. Santini ZI, Jose PE, Cornwell EY, Koyanagi A, Nielsen L, Hinrichsen $C$ et al. Social disconnectedness, perceived isolation, and symptoms of depression and anxiety among older Americans (NSHAP): a longitudinal mediation analysis. Lancet Public Health 2020;5(1):e62-e70. https://doi.org/10.1016/s2468-2667(19)30230-0

20. Chevance A, Gourion D, Hoertel N, Llorca PM, Thomase P, Bocherf R et al. Ensuring mental health care during the SARS-CoV-2 epidemic in France: A narrative review. Encéphale 2020;46(3):196-201. https://doi.org/10.1016/j.encep.2020.04.005

21. Yip PS, Cheung YT, Chau PH, Law YW. The impact of epidemic outbreak: the case of severe acute respiratory syndrome (SARS) and suicide among older adults in Hong Kong. Crisis 2010;31(2):86-92. https://doi.org/10.1027/0227-5910/a000015

22. Chan SM, Chiu FK, Lam CW, Leung PY, Conwell Y. Elderly suicide and the 2003 SARS epidemic in Hong Kong. Int J Geriatr Psychiatry 2006;21(2):113-8 https://doi.org/10.1002/gps.1432

23. Morin CM, Benca R. Chronic insomnia. Lancet 2012;379(9821):1129-41. https://doi.org/10.1016/s0140-6736(11)60750-2

24. Patel D, Steinberg J, Patel P. Insomnia in the elderly: a review. J Clin Sleep Med 2018;14(6):1017-24. https://doi.org/10.5664/icsm.7172

25. Goethals L, Barth N, Guyot J, Hupin D, Celarier T, Bongue B. Impact of home quarantine on physical activity among older adults living at home during the COVID-19 
pandemic: Qualitative interview study. JMIR Aging 2020;3(1):e19007.

https://doi.org/10.2196/19007

26. Guralnik JM, Ferrucci L, Simonsick EM, Salive ME, Wallace RB. Lower-extremity function in persons over the age of 70 years as a predictor of subsequent disability. $\mathrm{N}$ Engl J Med 1995;332(9):556-61. https://doi.org/10.1056/NEJM199503023320902

27. The Royal Australian College of General Practitioners. Your GP, expert advice when it matters most. 2020. https://www.expertadvicematters.com.au/

28. Tsai HH, Tsai YF, Wang HH, Chang YC, Chu HH. Videoconference program enhances social support, loneliness, and depressive status of elderly nursing home residents. Aging Ment Health 2010;14(8):947-54. https://doi.org/10.1080/13607863.2010.501057

29. Kivelitz L, Schulz H, Melchior H, Watzke B et al. Effectiveness of case managementbased aftercare coordination by phone for patients with depressive and anxiety disorders: study protocol for a randomized controlled trial. BMC Psychiatry 2015;15;90. https://doi.org/10.1186/s12888-015-0469-y

30. Banerjee D. The COVID-19 outbreak: Crucial role the psychiatrists can play. Asian J Psychiatry. 2020;102014.

http://niioz.ru/upload/medialibrary/cc2/cc28ac939f7946a6ba864f1355e36c6f.pdf 